Review

\title{
Carcinogenic risks of prenatal ionizing radiation
}

\author{
Robert L. Brent* \\ Thomas Jefferson University, Alfred I. duPont Hospital for Children, Room 308, A/R Building, PO Box 269, Wilmington, DE 19899, USA
}

\begin{abstract}
S U M M A R Y
The risk of cancer in offspring who have been exposed to diagnostic X-ray procedures while in utero has been debated for 55 years. High doses at high dose rates to the embryo or fetus (e.g. $>0.5 \mathrm{~Gy}$ ) increase the risk of cancer. This has been demonstrated in human epidemiology studies as well as in mammalian animal studies. Most pregnant women exposed to diagnostic X-ray procedures or the diagnostic use of radionuclides receive doses to the embryo or fetus $<0.1 \mathrm{~Gy}$. The risk of cancer in offspring exposed in utero at a low dose such as $<0.1 \mathrm{~Gy}$ is controversial and has not been determined.
\end{abstract}

Keywords:

Cancer

Carcinogenic risks

Fetus

Ionizing radiation (c) 2013 Elsevier Ltd. All rights reserved.

\section{Introduction}

In 1950-51, I was working in the radiation embryology section of the University of Rochester Medical Center's Atomic Energy Project. We had submitted an abstract to the Anatomy Society meetings in Detroit [1]. The completed manuscript that was submitted to Cancer Research was titled, 'Cancer induced in rat embryos by roentgen irradiation'. The editors rejected the manuscript and stated that if the embryos had developed cancer, there would have been a much higher mortality. So we changed the title to 'Neoplasia induced in rat embryos by roentgen irradiation' and the manuscript was accepted [2]. We examined the tumors as they first appeared and continued to grow (Fig. 1). Many of the tumors became anaplastic and contained many undifferentiated cells with a high mitotic index. At birth, most of the tumors were gone. However, there were a few pyknotic cell remnants that were still present. We followed 300 radiated survivors and controls for 4 years and these irradiated animals did not have a higher incidence of cancer than the controls.

We put this project aside with the tentative conclusion that the embryo was less vulnerable to the carcinogenic effects of low exposures of ionizing radiation than the postnatal animal.

Liane Russell [3,4] and our laboratory [5,6] had already described 'the all or none phenomenon', which indicated that the pre-somite mammalian embryo was less vulnerable to the teratogenic effects of ionizing radiation. The embryo was very vulnerable to the lethal effects of radiation; however, the surviving embryos did not have an increased risk of birth defects.

\footnotetext{
* Tel.: +1 302651 6880; fax: +1 3026516888

E-mail address: rbrent@nemours.org.
}

When Alice Stewart published her research results, a 60-year controversial discussion was initiated. Stewart et al. [7-10] suggested that the human embryo was more vulnerable to the leukemogenic effects of radiation and in later publications concluded that other childhood cancers also occur more frequently in persons exposed in utero to diagnostic radiologic procedures (primarily pelvimetry) (Fig. 2). These authors initially estimated that a 1-2 rad in-utero radiation exposure increases the risk of leukemia developing in the offspring by a factor of 1.5 to 2.0 over the natural incidence. This incidence is considerably greater than the increase resulting from 2 rad delivered to an adult population. In fact, an increase in the incidence of leukemia after an adult population exposure of 2 rad would be difficult to document, even for very large population groups [11,12]. Dr Stewart became a spokesperson for anti-radiation groups. She appeared as a plaintiff expert in radiation litigation and was even a plaintiff expert against her own country in a case before the World Court in which Ireland was suing the UK, claiming that a British nuclear facility (Sellafield's Fuel Handling Plant) was contaminating the Irish sea and causing increased cases of birth defects and cancer in the inhabitants on the east coast of Ireland. After more than a decade of litigation the World Court decided in favor of the UK [13]. Dr Stewart claimed that the embryo was many times more vulnerable to the carcinogenic effects of radiation than children and she was critical of scientists who disagreed with her $[8,14]$.

As a medical and graduate student and part-time instructor, I did not have time to further pursue the question of the resistance of the embryo to the carcinogenic effects of radiation. However, there were many publications exposing animals to carcinogenic agents. In particular, urethan (urethane; ethyl carbamate) was used by Klein [15] and Vesselinovitch et al. [16] to produce neoplasia in rodents. Only a few of the investigators utilizing urethan exposed pregnant animals to this carcinogenic agent. Klein [15] reported 
B
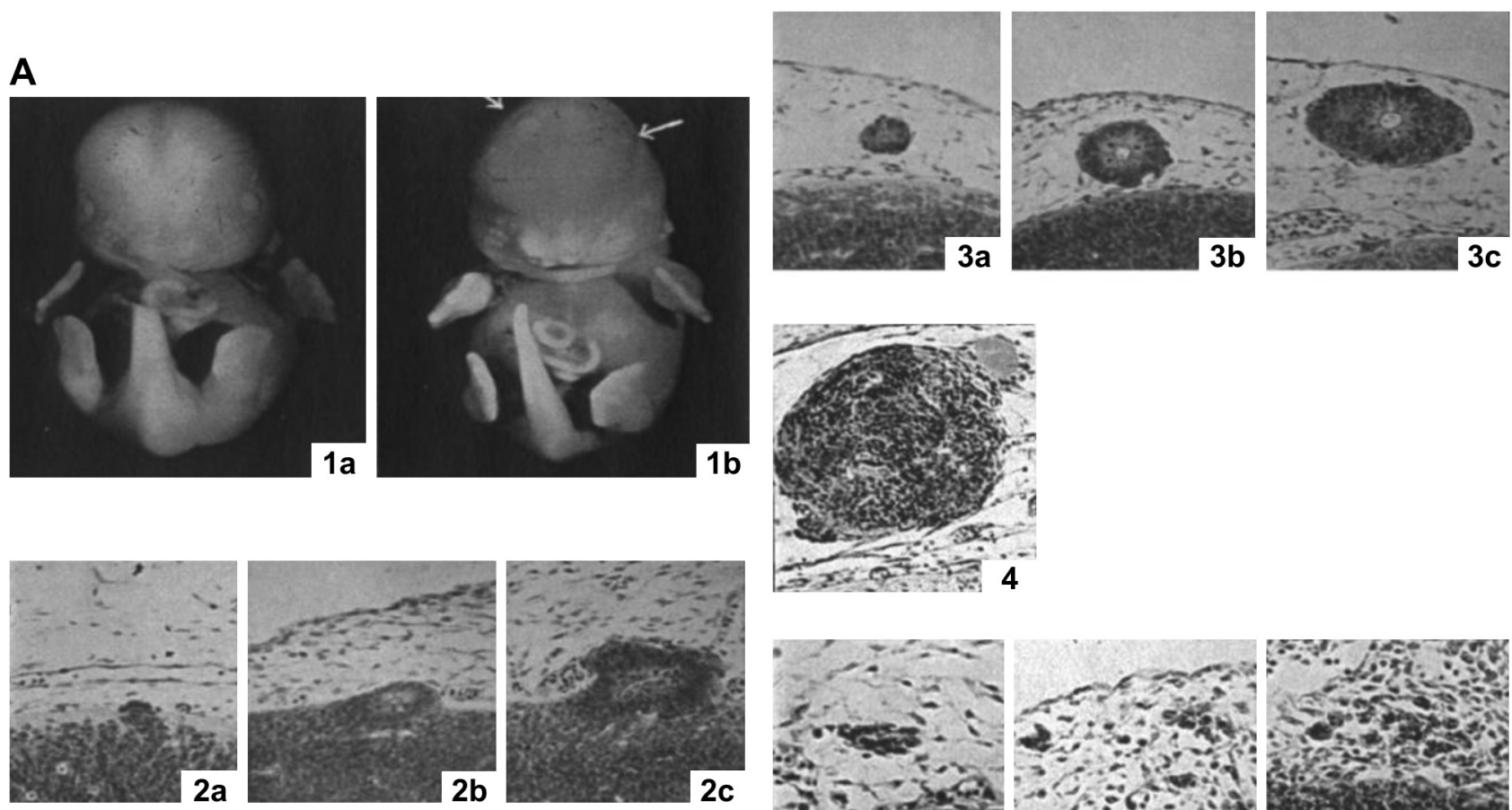
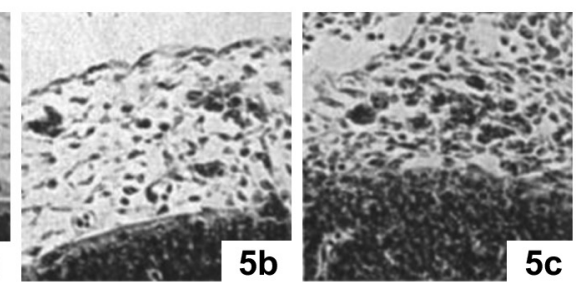

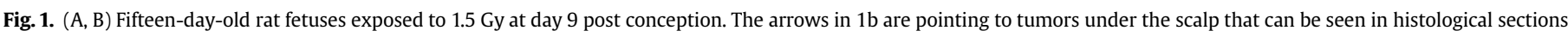

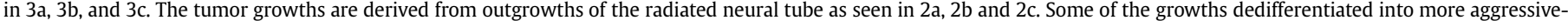

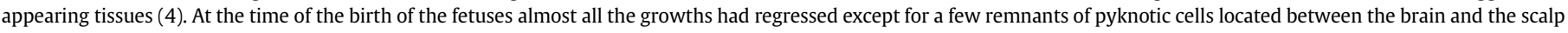
$(5 a, 5 b$, and $5 c)$. All photographs are reproduced with permission from Wilson et al. [2].

that cesarean-delivered mice exposed in utero had significantly fewer lung tumors than animals treated postnatally. Significantly more tumors per lung were observed in mice injected with urethan at 47 days of age than at birth, suggesting an increased susceptibility with age. Vesselinovitch et al. [16] exposed pregnant mice on

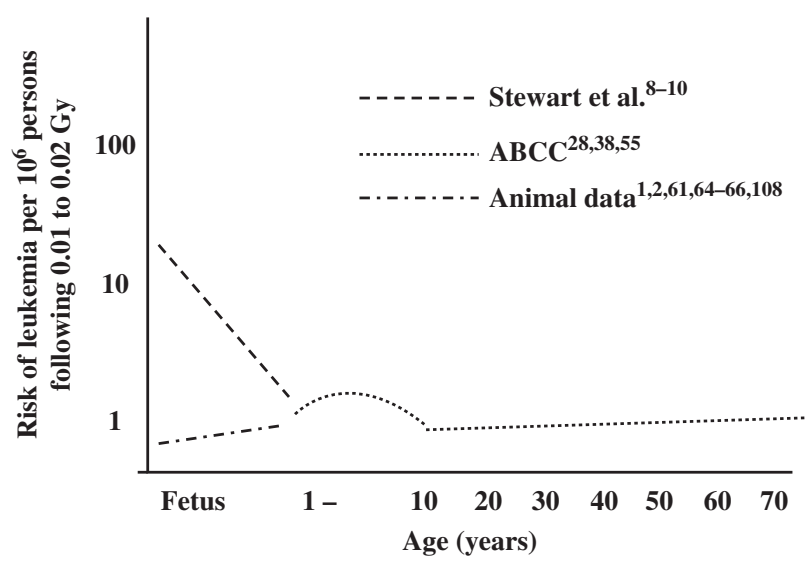

Fig. 2. Risk of cancer from in-utero radiation. When Stewart first reported the risks of cancer in the offspring of pregnancies in which the mother had been exposed to diagnostic radiological studies in the 1950s, the risk of leukemia was stated as one to two orders of magnitude greater than the risk of cancer following similar exposures in childhood. Children were believed to be slightly more vulnerable than adults. Animal studies were inconsistent, but many of the animal studies were negative and many of the studies did not expose the pregnant animals to doses of $<0.10 \mathrm{~Gy}$. ABCC, Atomic Bomb Casualty Commission. multiple days in mid pregnancy (days 12-18). The incidence of liver and lung tumors was significantly higher in mice exposed to this carcinogen at the end of gestation. Neonatally treated animals developed all of the tumor types more readily than those exposed to the carcinogen in utero and also developed leukemia which did not occur in the in-utero-exposed population. The urethan animal studies reinforced the animal studies from our laboratory, which indicated that the fetus had lower carcinogenic risks from mutagenic or carcinogenic agents when compared to the postnatal animal's vulnerability.

\section{Human studies concerning the vulnerability of the embryo to the carcinogenic risks of ionizing radiation}

Lilienfeld [17] reviewed the epidemiologic considerations with respect to leukemogenesis. His results, confirmed by others [1821] support the thesis that diagnostic radiation absorbed in utero was associated with an increased risk of leukemia. Six of nine studies reported in Lilienfeld's paper indicate a 1.3-1.8-fold increase in the risk of leukemia after diagnostic radiation exposure in utero. Lilienfeld states: 'When one considers the variety of control groups used and the sampling variability, the results are remarkably consistent in showing an excess frequency of leukemia among children of radiation-exposed pregnant mothers [17].' Diamond et al. [22] confirmed and extended the observation of a three-fold increased incidence of leukemia in children exposed to diagnostic radiation in utero. Interestingly, this effect did not occur in the African-American population. When MacMahon [23] extended his studies, the 1.5-fold excess leukemia incidence remained, but the excess in other childhood cancers was no longer present (Table 1). 
Table 1

Risk of specific and total childhood cancers in offspring of women undergoing prenatal diagnostic X-ray procedures: case-control studies. ${ }^{\mathrm{a}}$

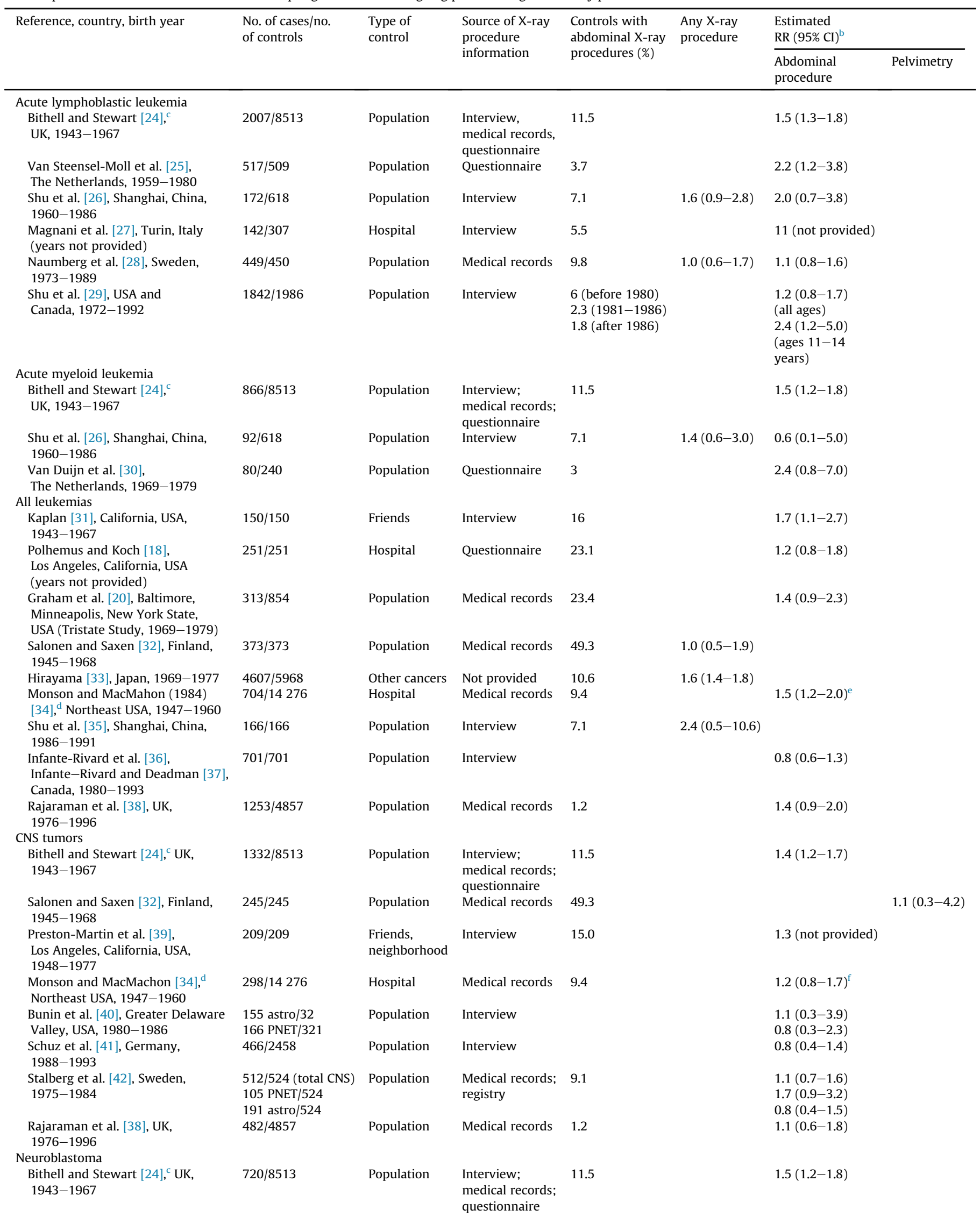


Table 1 (continued)

\begin{tabular}{|c|c|c|c|c|c|c|c|}
\hline \multirow[t]{2}{*}{ Reference, country, birth year } & \multirow[t]{2}{*}{$\begin{array}{l}\text { No. of cases/no. } \\
\text { of controls }\end{array}$} & \multirow[t]{2}{*}{$\begin{array}{l}\text { Type of } \\
\text { control }\end{array}$} & \multirow{2}{*}{$\begin{array}{l}\text { Source of X-ray } \\
\text { procedure } \\
\text { information }\end{array}$} & \multirow{2}{*}{$\begin{array}{l}\text { Controls with } \\
\text { abdominal X-ray } \\
\text { procedures (\%) }\end{array}$} & \multirow[t]{2}{*}{$\begin{array}{l}\text { Any X-ray } \\
\text { procedure }\end{array}$} & \multicolumn{2}{|l|}{$\begin{array}{l}\text { Estimated } \\
\mathrm{RR}(95 \% \mathrm{CI})^{\mathrm{b}}\end{array}$} \\
\hline & & & & & & $\begin{array}{l}\text { Abdominal } \\
\text { procedure }\end{array}$ & Pelvimetry \\
\hline \multicolumn{8}{|l|}{ Bone tumors } \\
\hline $\begin{array}{l}\text { Bithell and Stewart [24], }{ }^{\mathrm{C}} \mathrm{UK} \\
\text { 1943-1967 }\end{array}$ & $244 / 8513$ & Population & $\begin{array}{l}\text { Interview; } \\
\text { medical records; } \\
\text { questionnaire }\end{array}$ & 11.5 & & $1.1(0.7-1.7)$ & \\
\hline \multicolumn{8}{|l|}{ Ewing's sarcoma } \\
\hline Winn et al. (1992) [43], USA, & $204 / 204$ & Population & Interview & 27.5 & & $0.8(0.5-1.2)$ & \\
\hline multicenter (years not provided) & $191 / 191$ & Siblings & Interview & 17.3 & & $1.5(0.8-3.2)$ & \\
\hline \multicolumn{8}{|l|}{ Rhabdomyosarcoma } \\
\hline $\begin{array}{l}\text { Gufferman et al. [44], USA, } \\
\text { multicenter, 1962-1988 }\end{array}$ & $319 / 319$ & Population & Interview & 6.8 & & $1.4(0.7-2.9)$ & \\
\hline \multicolumn{8}{|l|}{ Total childhood cancer } \\
\hline $\begin{array}{l}\text { Bithell and Stewart [24], }{ }^{\mathrm{C}} \mathrm{UK} \\
\text { 1943-1967 }\end{array}$ & $8513 / 8513$ & Population & $\begin{array}{l}\text { Interview; } \\
\text { medical records; } \\
\text { questionnaire }\end{array}$ & 11.5 & & $1.5(1.3-1.6)$ & \\
\hline $\begin{array}{l}\text { MacMahon [45], }{ }^{\mathrm{d}} \text { Northeast USA, } \\
\text { 1947-1954 }\end{array}$ & $556 / 7230$ & Hospital & Medical records & 10.6 & & $1.5(1.2-1.8)^{\mathrm{e}}$ & \\
\hline $\begin{array}{l}\text { Monson and MacMahon [34], } \\
\text { Northeast USA, 1947-1960 }\end{array}$ & $1342 / 14276$ & Hospital & Medical records & 9.4 & & $1.3(0.95-1.7)^{\mathrm{e}}$ & \\
\hline $\begin{array}{l}\text { Rajaraman et al. [38], UK, } \\
\text { 1976-1996 }\end{array}$ & $2690 / 4857$ & Population & Medical records & 1.2 & & $1.1(0.9-1.4)$ & \\
\hline
\end{tabular}

RR, relative risk; CI, confidence interval; CNS, central nervous system; PNET, primitive neuroectodermal tumour.

a Adapted from Little. [46].

b RR and CI values are presented to one decimal place (rounded), except that one CI value is presented as 0.95 (rather than 1.0).

c Initial Oxford Survey of Childhood Cancer Case-Control Study (Stewart et al. ${ }^{10}$ ) was extended to include 12 additional birth years and an increase to 8513 cancer cases

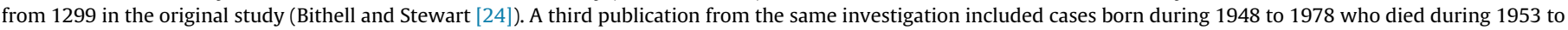
1979 (Knox et al. [47]).

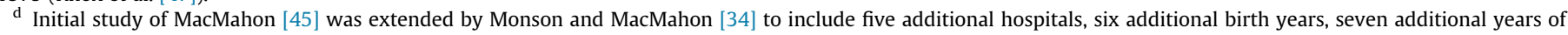
childhood cancer deaths, an increase to 1429400 children from 734243 in the original study.

e Results for children who died from cancer before their 10th birthday.

f Results for children who died from cancer before their 20th birthday; confidence interval computed from data in Monson and MacMahon. [34].

Several associations of these data should be pointed out. In the studies of Stewart and colleagues [7,10], there was a higher incidence of previous abortion in the mothers receiving pelvimetry, and the children in the pelvimetry group had a higher incidence of upper respiratory infections before the development of leukemia. Others reported that infants with a strong family history of allergy are also more susceptible to radiation-induced leukemia when exposed to diagnostic radiation in utero. The problem with these data is that patients with an allergic history and no exposure to radiation had a higher frequency of leukemia than did other groups that had received radiation in utero [48].

Of the 86 persons exposed in utero at Nagasaki, none developed leukemia [8]. These persons received considerably higher doses of radiation than did those patients in the previous studies.

Shiono et al. [49] examined the potential risk of diagnostic Xrays in the 44908 pregnant patients studied in the Collaborative Perinatal Project of the National Institute of Neurological and Communicative Disorders and Stroke. These findings were surprising in that they reported a statistically increased relative risk for malignancies in the offspring of mothers who were exposed before pregnancy (preconception) [relative risk (RR): 2.61; 90\% confidence limits (CL): 1.26-5.85]. However, there was no statistically significant increase in the risk of malignant or benign tumors in the offspring of mothers who were exposed to radiation during pregnancy (RR: 1.09 ; 90\% CL: $0.47-2.40$ for malignant neoplasms; and RR: 0.94; 90\% CL: $0.46-1.82$ for benign neoplasms). Court-Brown et al. [50] evaluated the incidence of leukemia in 39166 offspring of mothers who had been irradiated in utero, and Salonen [51] studied the relationship between pregnancy radiation exposure and childhood cancers. Neither study could establish a statistically significant increase in leukemia (Table 2).

Although it is true that the population of offspring exposed in utero in Hiroshima and Nagasaki did not have an increased incidence of leukemia and other childhood cancers during the childhood years, they have of course developed cancer as adults (Fig. 3).

A larger number of cancers must accumulate before we can reliably establish a risk of cancer in adults who were exposed in utero. Whether there is an increased risk has been partially answered by Preston et al. [67] One conclusion is certain: the risk of developing cancer as an adult from in-utero radiation is below the risks of childhood cancer that have been suggested by several investigators (Fig. 4) [7-10,17-19,21].

Hoshino et al. [68] reported no increase in leukemia in a study of 17000 children of parents who had received radiation before conception. The question arises as to what extent the same biases that contribute to the increased risk of leukemia in the cases of radiation exposure before conception also affect the in-utero radiation cases. Graham et al. [20] pointed out that children of mothers with a history of abortion or stillbirths also had children with a higher risk of leukemia.

Miller [69] and others [56,70,71] do not believe that the risk of prenatal radiation is as great as Stewart suggests. Miller writes:

It is surprising that in Stewart's studies minimal doses of x-rays are equally oncogenic whether exposure occurred before conception or during pregnancy, whether the neoplasm studied was leukemia or any other major cancer of childhood, and whether the study was based on interviews, which may be biased, or from hospital records. Taken in aggregate, the similarity of results, in the absence of a dose-response effect or of supporting data from animal experimentation, raises a question about biologic plausibility of a causal relationship.

Furthermore, Miller [69] points out that siblings of leukemic children have a risk of childhood leukemia of 1 in 720 in the first 10 
Table 2

Cancer mortality rates in cohorts of children whose mothers underwent diagnostic $\mathrm{X}$-ray procedures during pregnancy. ${ }^{\mathrm{a}}$

\begin{tabular}{|c|c|c|c|}
\hline Reference, location & $\begin{array}{l}\text { No. of cancer deaths; } \\
\text { no. of children } \\
\text { exposed in utero }^{\text {b }}\end{array}$ & $\begin{array}{l}\text { Total cancer } \\
{[\mathrm{RR}(95 \% \mathrm{CI})]}\end{array}$ & $\begin{array}{l}\text { Leukemia } \\
{[R R(95 \% \mathrm{CI})]}\end{array}$ \\
\hline $\begin{array}{l}\text { Murray et al. [52] } \\
\text { (Rochester, NY) }\end{array}$ & $3(\mathrm{~L}) ; \sim 6740^{\mathrm{c}}$ & & $0.9(0.3-3.1)$ \\
\hline $\begin{array}{l}\text { Court Brown et al. [50] } \\
\quad{\text { (Edinburgh })^{\mathrm{d}}}^{\text {Edinb }}\end{array}$ & $9(\mathrm{~L}) ; 39166$ & & $0.9(0.4-1.6)$ \\
\hline Lewis [53] (London) & $1(\mathrm{~L}) ; 11443$ & & $0.4(0.1-2.6)$ \\
\hline $\begin{array}{l}\text { Griem et al. [54] } \\
\text { (Chicago) }\end{array}$ & 4 (I L, 3 O); 982 & $1.2(0.4-4.0)$ & $0.4(0.1-2.6)$ \\
\hline $\begin{array}{l}\text { Oppenheim et al. } \\
{[55,56] \text { (Chicago) }^{\mathrm{e}}}\end{array}$ & $1(\mathrm{~L}) ; 393$ & & $0.7(0.1-5.0)$ \\
\hline $\begin{array}{l}\text { Diamond et al. [22] } \\
\text { (Baltimore) }\end{array}$ & 13 (6 L, 7 0); 19889 & $1.1(0.5-2.1)$ & $1.6(0.6-4.6)$ \\
\hline $\begin{array}{l}\text { Shiono et al. [49] } \\
\quad \text { (USA, multicenter) }\end{array}$ & $7 ; \sim 5000^{\mathrm{f}}$ & $1.1(0.5-2.4)$ & \\
\hline $\begin{array}{l}\text { Golding et al. [57] } \\
\text { (UK, national) }\end{array}$ & $12 ; \sim 3000^{g}$ & $1.2(0.6-2.5)$ & \\
\hline $\begin{array}{l}\text { Combined small } \\
\text { cohorts (ICRP [58]) }\end{array}$ & 7 & $4.6(0.9-25.1)$ & \\
\hline Dempster [59] & {$[0 ; 148]$} & & \\
\hline Milis et al. [60] & {$[0 ; 190]$} & & \\
\hline Lejeune et al. [61] & {$[2 ; 491]$} & & \\
\hline Magnin [62] & {$[1 ; 5353]$} & & \\
\hline Nokkentved [63] & {$[0 ; 152]$} & & \\
\hline Hagstrom et al. [64], & {$[4 ; 649]$} & & \\
\hline $\begin{array}{l}\text { Ray et al. [65] } \\
\text { (Ontario, Canada) }\end{array}$ & $4 ; 5590$ & $0.7(0.3-1.8)$ & \\
\hline
\end{tabular}

a Adapted from Doll and Wakeford [66] and ICRP. [58].

b The number of leukemias (L) and other cancers $(0)$ are given when available.

c A total of 140438 children aged $<20$ years were included; $\sim 6460$ of the 6740 exposed mothers had pelvimetry or other abdominal X-ray procedures during pregnancy.

$\mathrm{d}$ Doll pointed out his concerns about the adequacy of the identification of irradiated women that arose when he tried to extend the Court Brown et al. [50] study. Doll indicated that some of the findings may therefore be unreliable (Doll and Wakeford [66]).

e Subsequent follow-up study of Griem et al. [54].

f A total of 55908 live births were studied; 10\% of the mothers had abdominal $\mathrm{X}$-ray procedures during pregnancy.

g A total of 16193 live births were studied; 18\% of the mothers had abdominal, non-abdominal or dental X-ray procedures during pregnancy.

$\mathrm{h}$ Exposure in Hagstrom et al. [64] was to radioactive iron $\left({ }^{59} \mathrm{Fe}\right)$ administered during pregnancy. The RR and 95\% CI for this small cohort was 6.1 (1.7-15.8). years of their life, which is greater than the 1:2000 risk of leukemia after pelvimetry exposure and the 1:3000 probability of leukemia in the general population of children followed for 10 years (Table 3 ). Stewart and Kneale [7] reinforces the contention that radiation may not be the only etiologic factor responsible for the induction of malignancy because of unirradiated siblings of the irradiated patient population with a higher incidence of leukemia also had an incidence higher than in control siblings and in control patients. This observation certainly would indicate that genetic or other environmental factors may be important in the etiology of leukemia.

At present, some investigators believe that in-utero exposure to small amounts of radiation increased the risk of leukemia and other malignancies, whereas others seriously question the contention that the embryo is markedly more sensitive to the leukemogenic effects of irradiation when compared with the child or adult. Until the mechanism is understood, there will be doubt concerning the magnitude of the role of in-utero diagnostic radiology studies in leukemia induction. The increased incidence of cancer in children exposed to in-utero diagnostic radiation should be clarified in view of the fact that much higher doses of radiation to animal embryos and to the children exposed in utero at Hiroshima and Nagasaki have not resulted in a marked increase in the incidence of cancers from higher doses of radiation, which one would expect if the embryo were as sensitive to the carcinogenic effects of radiation as Stewart and colleagues suggest (Table 2) (Figs. 3 and 4) [74-77].

One cannot overemphasize either the importance of the multiplicity of factors or the difficulties involved in identifying and controlling for such factors. Even laboratory experiments concerned with tumor production are difficult to interpret. For example, Ross and Bras [48] reported that the incidence of spontaneous tumors varied with the diet and weight of the animals. Heavier animals on high-protein diets had a higher incidence of tumors than did the lighter rats on low-protein diets. Hence, there are many unanswered questions pertaining to the relationship between leukemia and malignancy and in-utero radiation exposure.

Because of the introduction of new diagnostic techniques, such as the use of ultrasound, and because of the concerns about the risks of radiation, fewer pregnant patients will be exposed in the future. Therefore it is unlikely that adequate numbers of exposed patients will be available to evaluate the carcinogenic risks of inutero diagnostic radiation. MacMahon [21] in his editorial in the

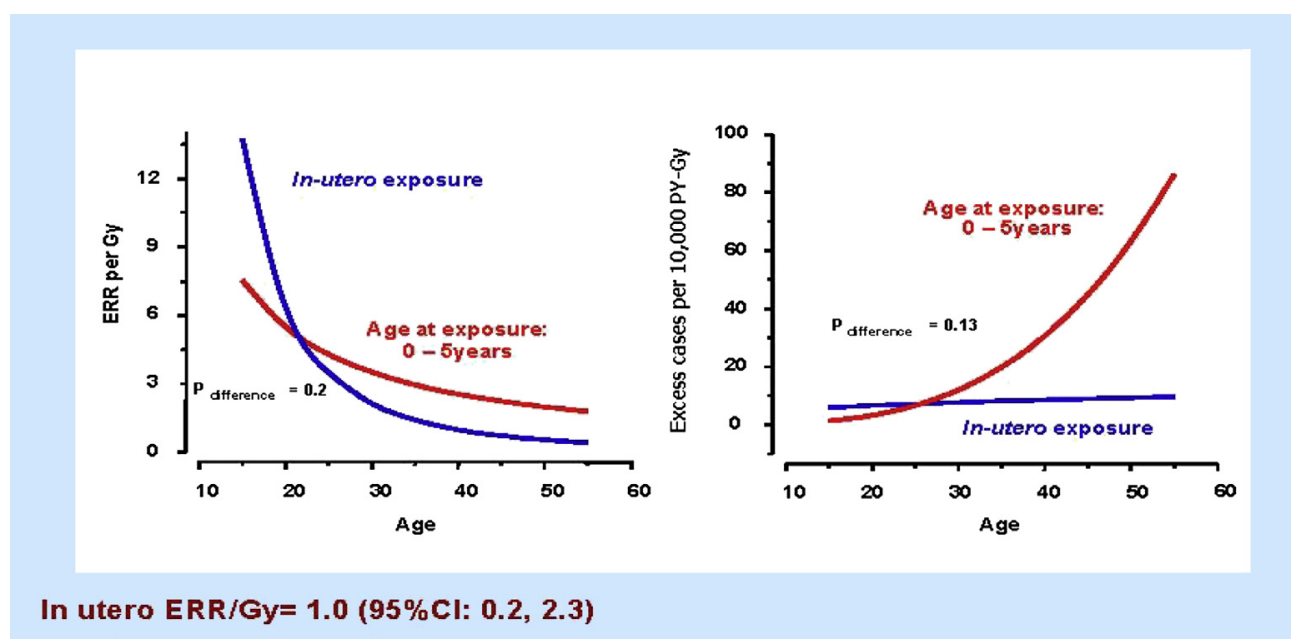

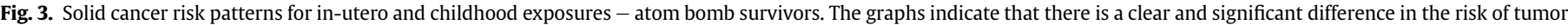

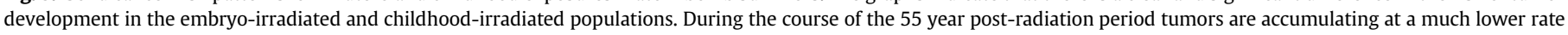
in the irradiated in-utero population. ERR, excess relative risk; PY, person-years; CI, confidence interval. Reproduced with permission from Preston et al. [67]. 


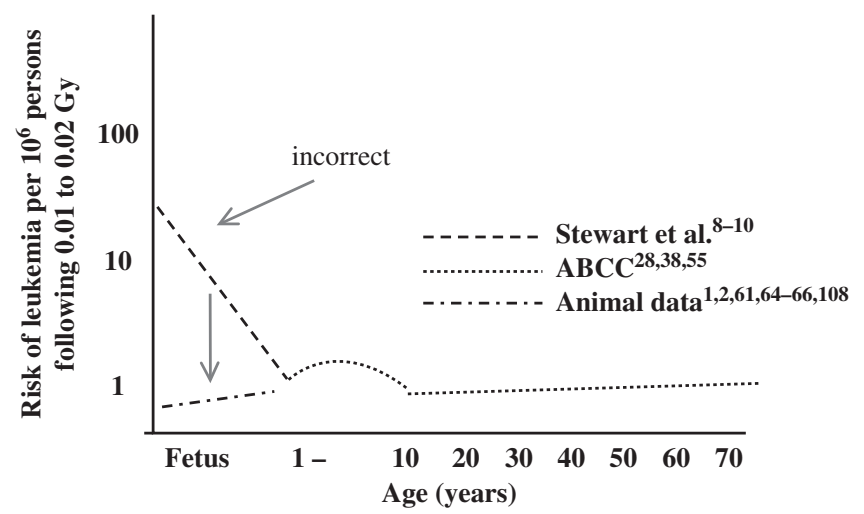

Fig. 4. Risk of leukemia in children following radiation exposure during pregnancy. This graph illustrates the modification proposed for Fig. 2, which indicates that the risk of leukemia from radiation of the embryo/fetus is not one to two orders greater than for the child, but actually lower than the risk for the child.

New England Journal of Medicine wrote that 'It seems likely that the question of the association between fetal irradiation and childhood cancer will fade into medical history unresolved and remain a source of more confusion than enlightenment.'

There is little disagreement with the concept that radiation may represent a carcinogenic risk to the embryo and adult and that there may be different risks per rad at different stages of development. The concept that is difficult to explain from a basic science viewpoint is, "Why would embryonic cells be orders of magnitude more sensitive to radiation-induced cancer than cells of children or adults?'

Recent publications have provided added perspectives, data, and interpretations of the prior publications [78-86]. Boice and Miller [78] point out that numerous epidemiologic studies have been performed. Positive associations for an increased incidence of cancer after in-utero diagnostic radiation exposures have been derived almost exclusively from case-control studies (Tables $1-3$ ), whereas almost all of the cohort studies have found no association (Figs. 3 and 4). It is of great interest that the in-utero atomic bomb population did not demonstrate an increase in childhood leukemia

Table 3

Risk of leukemia.

\begin{tabular}{|c|c|c|}
\hline Group & Risk & Latency \\
\hline Identical twin of a leukemic twin & $1: 5$ & Weeks to months \\
\hline Radiation-induced polycythemia & $1: 6$ & $10-15$ years \\
\hline Bloom syndrome & $1: 8$ & $<10$ years of age \\
\hline $\begin{array}{l}\text { Hiroshima survivors }<1000 \mathrm{~m} \\
\text { hypocenter }\end{array}$ & $1: 60$ & $3-12$ years \\
\hline Down syndrome & $1: 95$ & Weeks to months \\
\hline $\begin{array}{l}\text { Radiation treatment of ankylosing } \\
\text { spondylitis }\end{array}$ & $1: 270$ & 15 years \\
\hline Siblings of a leukemic child & $1: 720$ & 10 years \\
\hline $\begin{array}{l}\text { Combined background risk of } \\
\text { leukemia plus radiation risk } \\
\text { from Stewart }\end{array}$ & $1: 2000$ & 10 years \\
\hline $\begin{array}{l}\text { Additional risk of in-utero } \\
\text { diagnostic radiation studies } \\
\text { (Stewart et al. [8]) }\end{array}$ & $1: 6000$ & 10 years \\
\hline $\begin{array}{l}\text { In-utero diagnostic radiation } \\
\text { (RERF) data and other cohort } \\
\text { studies }\end{array}$ & $\begin{array}{l}\text { Risk the same for } \\
\text { exposure during } \\
\text { childhood but } \\
\text { actual risk is } \\
\text { uncertain (Miller } \\
\text { [72]; Brent [73]) }\end{array}$ & Lifetime \\
\hline US Caucasian aged $<15$ years & $1: 3000$ & 10 years \\
\hline
\end{tabular}

RERF, Radiation Effects Research Foundation.

a Modified from Miller et al. [69]. despite the fact that many in the in-utero population were exposed to high doses of acute irradiation.

Because many of the positive associations have been derived from case-control studies, the questions of confounding factors have been raised to explain the findings. Twin studies have been used to eliminate some of the confounding factors [87-89]. Although the reports of Mole [89] and Harvey et al. [87] were positive, the Rodvall study [88] was not statistically significant.

The most recent estimates of the carcinogenic risk of in-utero radiation have moved from two extremes. The first viewpoint popularized by Stewart $[8,10]$ suggested a risk of one or two orders greater than the carcinogenic risk of postnatal exposure to children and adults. Based on animal data and the Radiation Effects Research Foundation (RERF) data, it appeared that the embryo and fetus may actually have a lower risk than children exposed postnatally. Boice and Miller [78] have concluded that the more recent data have reduced the discrepancy between these two extreme viewpoints. Based on the reports of Muirhead and Kneale [82] and Mole [89] they believe that 'The risk estimate associated with intrauterine radiation is not substantially greater than that seen following childhood irradiation.'

Doll and Wakeford [90] expressed their opinion about the carcinogenic effect of intrauterine radiation and concluded that 'Irradiation of the fetus in utero increases the risk of childhood cancer, and increases the risk from exposures of the order of $10 \mathrm{mGy}$, and that in these circumstances the excess risk is 6\% per Gy.'

The atomic bomb survivors of in-utero irradiation have been followed into adulthood, and the incidence of cancer in this population has been studied [86]. Although some of the exposures to this population of pregnant women was considerably higher than the exposure from the population exposed to radiation from pelvimetry, there was only a small excess of adult tumors among the atomic bomb survivors exposed in utero (Tables 2 and 3 ).

Boice and Miller [78] conclude:

Learned debate continues as to the causal nature of low level intrauterine radiation and subsequent cancer risk. The association is not questioned, but the etiologic significance is. Different scientists interpreting the same data have different opinions as to the causal nature of the association and the possible level of risk.

\section{Box 1}

Arguments supporting a causal association between prenatal radiation and childhood leukemia and cancer

1. Consistency. Practically all studies are statistically consistent, with relative risk of 1.40 for leukemia $[23,66,91]$.

2. Dose response. Risk of childhood cancer was found to increase with number of X-ray films [68].

3. Coherence. Apparent lower risk of childhood cancer in birth cohorts born in years when dose per film was lower [66,92].

4. Recall bias is unlikely to be a major factor [45].

5. Confounding variables have been sought, but none has been found $[68,34]$.

6. Selection bias related to reason for radiographic examination is not supported by case-control studies of twins $[87,89]$.

7. Risk estimates after intrauterine exposures are generally comparable to risks after childhood exposures for leukemia $[82,91]$. 
Box 2

Grounds for uncertainty regarding the causal nature of the association between prenatal radiation and childhood cancer

1. Atomic bomb in-utero study finds no excess of childhood cancer deaths [93], whereas a lower limit of 5.2 extra cancer deaths was predicted from the risk model based on obstetric X-ray data [7]. The central estimate of excess cancer deaths predicted was about 10 .

2. All major cohort studies are negative $[22,50,91]$.

3. Biological implausibility; the equality of relative risks associated with obstetric X-rays for leukemia and solid tumors is perplexing given the variability in tissue radiosensitivity, dissimilar origins, and different incidence patterns [94,95]. The extended MacMahon study did not find an increased risk for solid cancers [34].

4. Risk estimates appear greater for in-utero versus newborn exposures, for solid cancers [91].

5. Twin cohorts have lower risk of childhood cancer than singletons despite more frequent $X$-rays $[91,96,97]$.

6. Supporting animal evidence is weak $[95,98,99]$.

Boxes 1 and 2 summarize the opinion of John Boice and Robert Miller regarding the controversy pertaining to the carcinogenic risk of ionizing radiation exposure to the developing embryo following the National Council on Radiation Protection and Measurements (NCRP) annual meeting dealing with the developmental, reproductive, carcinogenic and mutagenic risks of ionizing radiation published in 1999 [78].

During the period from 1997 to 2013 there were other publications dealing with the carcinogenic risk of exposing the embryo to ionizing radiation besides Boice and Miller [78], the RERF program in Japan [67] and the publications of Wakeford $[66,90,100,101]$. Wakeford continued his estimate of the risks of cancer following in-utero radiation and persisted with the conclusion that the embryo was more vulnerable to the carcinogenic effects of ionizing radiation than the risks in exposed children.

The most important recent publication dealing with the carcinogenic risks of in-utero radiation was that by Preston et al. [67] ICRP 90 was published in 2003 and was titled 'Effects of prenatal irradiation (embryo and fetus)'. In 2013 an update of NCRP Handbook 54 was published as NCRP Report 174, 'Preconception and prenatal radiation exposure: health effects and protective guidance.' [102] Dr Martha Linet had final responsibility for the section on oncogenesis. Contributions and suggestions were submitted by other committee members to Dr Linet. Dr Roy Shore's critiques from the RERF program in Japan were particularly helpful.

Before reviewing the Preston et al. [67] the data pertaining to the case-control and cohort studies are examined.

\subsection{Case-control and cohort studies}

Alice Stewart and her colleagues were the first to indicate that diagnostic radiological studies of pregnant women could significantly increase the risk of cancer in the offspring $[9,10]$. Similar case-control studies were performed in eight other countries and they are summarized in Table 1. Some investigators were skeptical of Dr Stewart's conclusions because the results were partly based on medical histories obtained from the mother rather than from the medical records. However, later analyses utilized primarily medical records and the increased $R R>1.0$ persisted. Attempts to determine the actual fetal exposure of the pregnant women were not successful, since the exposures were never measured on the pregnant women whose offspring were part of the analysis.

There are 35 case-control studies listed in Table 1 dealing with childhood lymphoblastic leukemia, acute myeloid leukemia, all leukemias, CNS tumors, neuroblastoma, bone tumors, Ewing sarcoma, rhabdomyosarcoma and total childhood cancer. Twenty-five of the case-control studies were not statistically significant. Ten of the studies with $\mathrm{RR}>1$ were statistically significant. The consensus was that the case-control studies supported a RR of 1.2-1.3 based on a meta-analysis [101].

\section{Epidemiological cohort studies (Table 2)}

There were 17 cohort studies of the offspring of women who had been exposed to radiation during their pregnancy. None of the studies individually reported a statistically increased RR for cancer in the offspring. Cohort investigations to assess childhood cancer risks among those undergoing diagnostic X-ray procedures involving in-utero exposure included radiation-exposed populations ranging in size from $<200$ to nearly 40000 children. The largest cohort study in this group was the report of Court Brown et al. [50] This article was published in 1960 just a few years after Giles et al. [9] and Stewart et al. [10] had indicated that the embryo may be much more vulnerable to the carcinogenic effects of radiation. There were 39166 exposed and more than 1.5 million unexposed. There were nine leukemia subjects in the radiated population and 14 in the controls [RR: 0.9; 95\% confidence interval (CI): 0.4-1.6]. None of the cohort studies was statistically significant. The problem of cohort studies is that very large populations of exposed individuals are needed, which was not the case with most of these cohort studies.

\section{Environmental exposures: atomic bomb survivors (Preston et al. [67])}

Although there was no evidence of a dose-related increase in cancer mortality at ages prior to 15 years of age among the $\sim 2500$ persons who were in utero at the time of the bombings [103], as the cohort has grown older, a statistically significant excess relative risk (ERR) of solid cancers became apparent (ERR: $2.1 \mathrm{~Gy}-1$; $90 \% \mathrm{CI}$ : $0.2-6.0$ ), based on 10 deaths among those with weighted uterine doses $>0.01 \mathrm{~Gy}$ [80]. In a follow-up of cancer mortality risks during 1950 to 1992 comparing risks among a subset of persons who were in utero versus those who were 0 to $<6$ years of age at the time of the bombings, there were only two deaths from leukemia (both exposed to relatively low doses and none during childhood) in the in-utero cohort versus 24 among children $<6$ years of age at exposure (Fig. 3) [80].

Subsequently, Preston et al. [67] compared solid cancer incidence risks among in-utero cohort members aged 12-55 years during 1958 to 1999 (based on 94 cancers) with risks among survivors who were aged $<6$ years of age at the time of the bombings (based on 649 cancers). The difference in ERRs and excess absolute risks (EARs) between the two cohorts suggests that lifetime cancer risks at age 50 years following in-utero exposure are lower than risks for early childhood exposures. However, the investigators state, 'Additional follow-up of this cohort is necessary before definitive conclusions can be made about the nature of the risk for those exposed in utero' [67] (Figs. 3 and 4). The difference in ERRs and EARs between the two cohorts suggests that lifetime cancer risks at 50 years of age following in-utero exposure are lower than risks for early childhood exposure.

However, the investigators state that additional follow-up of this cohort is necessary before definitive conclusions can be made about the nature of the risks for those exposed in utero. ${ }^{, 67}$ The 
investigators also note that 'this study cannot provide information on the effect of radiation on the incidence of childhood cancers because comprehensive data on solid cancer incidence are unavailable for the period from 1945 to 1957.' Mortality follow-up for the in-utero cohort, however, was available from 1950 and indicated no deaths from childhood leukemia [80]. Another limitation is the small numbers of cancers in each dose category in the inutero cohort.

Nevertheless, this investigation is the only cohort study with long-term, continuous, active follow-up of a population with inutero radiation exposure and high-quality estimated doses for each subject.

\section{Animal studies}

Many animal studies were performed in which pregnant animals were irradiated with ionizing radiation and the risk of cancer in the offspring was evaluated in the offspring. A major problem with these studies is that very few of the protocols utilized exposures in the diagnostic range of clinical X-ray studies ( $<0.10 \mathrm{~Gy}$ ). So very few of the studies were planned to answer the question of the risk of diagnostic radiation to pregnant women.

Several studies have reported excess risks of various tumors in mice after in-utero irradiation, mostly after whole-body doses higher than $2 \mathrm{~Gy}$. Offspring of BC3F1 mice who received wholebody in-utero doses (17th day post coitus) ranging from 0.3 to 2.1 Gy (41-58 animals in each dose group) developed small increases in liver tumor occurrence [104]. Offspring of B6C3F1 mice exposed to a whole-body dose of $3.8 \mathrm{~Gy}$ in utero developed increased risk of pituitary, ovarian, liver, and bone tumors; an increase in lung tumors was statistically significant after doses of 1.9, 3.8, and $5.7 \mathrm{~Gy}$; and an elevation in malignant lymphoma, lymphocytic type, was statistically significant after 5.7 Gy [105].

In-utero irradiation [0.3 and $1 \mathrm{~Gy}$ (X-rays, whole body)] during day 10.5 postconception $\left(\mathrm{PT} \times \mathrm{HT} \mathrm{F}_{1}\right.$ ) did not induce an increased incidence of neoplasms in the offspring [106].

Studies assessing tumor risks in different strains of mice demonstrate high susceptibility of the ovaries for radiation-related tumor induction during the fetal period, with $0.25 \mathrm{~Gy}$ the lowest dose associated with a statistically significant increase $[105,107,108]$.

Other investigations found no excess cancer after in-utero irradiation of mice with 3 or 2 Gy $[99,109]$, although each of these studies showed increased risks of cancer in the mice following administration of similar doses postnatally. Although investigators found no excess cancer in BC3F1 mice after in-utero exposures to $0.3 \mathrm{~Gy}$, increased risks were seen in mice given the same dose postnatally [84].

Rugh et al. [110] in a very large study irradiated mice with $1 \mathrm{~Gy}$ on each day post conception and observed the incidence of tumors in the offspring as adults. There was no statistically significant increase in the incidence of tumors in adult animals from irradiation in utero on any day. Brent and Bolden [6] exposed pregnant mice to doses of $0.3,0.6$, and $0.9 \mathrm{~Gy}$ at $0.5,7.5,8.5,12.5$, and 16.5 days post conception. They also did not observe an increase in the incidence of tumors. However, the pre-sexually mature mouse was more vulnerable than the adult mouse to the leukemogenic effect of radiation.

Offspring of pregnant beagles treated with mean doses of 0.16 or $0.81 \mathrm{~Gy}$ at 8 th, 28th, or 55th days post coitus (120 dogs in each dose and treatment day group) experienced increases in mortality from total cancers that were not statistically significant, and statistically significant elevated mortality risks from lymphoma. Detailed assessment revealed that the increased risk of fatal neoplasms was most pronounced in beagles irradiated in the neonatal period [111].
These data suggest that irradiation in both the fetal and neonatal periods are associated with an increase of early onset and lifetime cancer risk. However, the lower-dose group (0.16 Gy) did not have an increased incidence of tumors.

Warkany et al. [112] studied the interaction of ethylnitrosourea and $\mathrm{X}$-irradiation in rats. The original goal of the investigators was to determine the effect of X-irradiation administered on the 16th day post conception on the incidence of tumors following the administration of ethylnitrosourea on the 20th day post conception. Sixteen months after delivery $62.2 \%$ of the rats that had received only the ethylnitrosourea during the fetal period had neurogenic tumors. After fetal irradiation on the 16th day post conception, followed by ethylnitrosourea 4 days later, $16.7 \%$ of the rats developed neurogenic tumors. The mechanisms of these unexpected findings, whereby irradiation before receiving an oncogenic drug reduced the incidence of cancer, have not been determined.

Nakano et al. [113] irradiated mice at various stages of pregnancy with 1 or $2 \mathrm{~Gy}$. Translocation frequencies in the peripheral blood T-cells, spleen cells, and bone-marrow cells were determined when the offspring were aged 20 weeks. The translocation frequency was very low in the mice that were irradiated in utero $(0.8 \%)$. The mice irradiated during days to weeks after birth had translocation frequencies of $5 \%$. The authors suggested that the abnormal cells in the fetus were replaced by normal fetal stem cells during the postnatal growth of the animal. If this phenomenon occurs in humans, it could explain why the fetus may be less vulnerable to the oncogenic effect of radiation than the child. Earlier research supporting the findings of Nakano et al. [113] found that X-irradiation of the rat embryo during early organogenesis resulted in the production of hundreds of small growths that resembled well-differentiated ependymomas or retinoblastomas (Fig. 1) [1,2]. As the embryo developed, some of the tumors dedifferentiated into more primitive growths. However, at term almost all the cytogenetically abnormal cells had regressed - similar to the result reported by Nakano et al [113].

\section{Counseling patients about the in-utero carcinogenic risks of ionizing radiation}

Although it is our opinion that a dose of $<0.10 \mathrm{~Gy}$ to the implanted embryo does not result in a significant increase risk for congenital malformations, intrauterine growth restriction, or fetal death (deterministic effects), low-risk tumorigenic or genetic hazards cannot be ruled out. Even if one believed that the tumorigenic (leukemogenic) effects of low-level radiation were real, let us examine how difficult it would be to use this information in counseling a patient who has received a dose of perhaps $2 \mathrm{rad}$ (0.02 Gy) during her pregnancy. According to Stewart et al. [7,8,10], the risk of leukemia after this exposure in utero is $1: 2000$ versus 1:3000 in unexposed controls over a 10-year period (Table 3). If one were inclined to recommend therapeutic abortion for this pregnancy because the probability of developing leukemia is $50 \%$ greater than controls, one would perform abortions in almost 2000 exposed non-leukemic subjects for every leukemic subject 'saved'. It is one thing to avoid radiation because of a potential or conjectured hazard, but it is another matter to recommend therapeutic abortion on this basis. If a physician were inclined to accept this increased probability $(1: 2000)$ as a risk great enough to recommend therapeutic abortion, he or she would be placed in a serious dilemma because there are other epidemiologic situations in which the risk of leukemia is greater. In fact, the hypothetical incremental risk for 2 rad of in-utero radiation is 1:6000 over a 10-year period. It is the combination of the control risk plus the incremental radiation risk that results in a 1:2000 risk for these patients. From Table 1 it should be clear that the risk of leukemia is greater in 'unirradiated' 
siblings of leukemics $(1: 720)$ than in patients subjected to diagnostic radiation (1:2000) if one uses Stewart's risk estimate.

Certainly, the position that all future pregnancies of parents with one leukemic child should be aborted would be untenable. One can carry this argument to its ridiculous extreme by advocating that all pregnancies should be aborted because of the risk of serious malformations is $\sim 30$ per 1000 deliveries (Table 3 ) and this does not include the probability of postnatal diseases occurring in these offspring. Some may interpret this as a facetious discussion, but the clinician and the patient must recognize that 'spontaneous' risks of pregnancy are two orders of magnitude greater than the theoretical risks of diagnostic radiation (Box 1 ).

\section{Conclusions and counseling advice}

The radiation risks determined from the A-bomb exposure to the populations in Hiroshima and Nagasaki have been referred to as the "gold standard" for determining radiation risks because the study was a large cohort study with a major effort to determine the actual exposure of each survivor. Yet we know that if individuals or populations are exposed to x-rays or gamma rays of different photon energy or length of exposure, the risks may deviate from the risks determined for the A-bomb survivors. Furthermore, there was a neutron component in the radiation from the A-bomb detonations. So one can assume that exposures to the embryo from an IVP or fluoroscopy in a pregnant mother may represent a different risk to the embryo per mGy than the A-bomb data. So that is why it is problematic to provide definitive carcinogenic risks for diagnostic radiologic studies utilizing x-rays or radionuclides. This article has discussed the subject of the carcinogenic risk of ionizing radiation to the embryo.

1. There is no doubt that if the exposure is high enough and of short duration, the carcinogenic risks are increased. Protracted continuous radiation of $0.02 \mathrm{~Gy} /$ day does not represent an increased carcinogenic risk. Acute radiation of $1.0 \mathrm{~Gy}$ at midgestation does represent an increased carcinogenic risk.

2. The embryo is less vulnerable to the carcinogenic effects of radiation the earlier in gestation it is exposed.

3. There are at least three viewpoints on the carcinogenic risks of $<0.10 \mathrm{~Gy}$ embryonic radiation.

(a) There is the scholarly, conservative view of Martha Linet who writes that the risk is very small and would not justify canceling a radiological study in a pregnant woman if the study is medically indicated. She also suggests that we wait to determine whether the risk increases based on future data from the Preston et al. study, which stated that 'additional follow-up of this cohort is necessary before definitive conclusions can be made about the nature of the risks for those exposed in utero.' [67]

(b) Richard Wakeford has been interested in this subject for decades. We first met many years ago when we were defense experts in litigation between the UK and Ireland regarding the allegation that the Sellafield Nuclear Facility was discharging nuclear 'waste' that was responsible for an increase in cancer and birth defects in the inhabitants on the East Coast of Ireland. The World Court deliberations ended after 10 years with a defense verdict. Wakeford's views have changed with time. One of his most recent publications indicates that he believes that $20 \%$ of childhood leukemia in the UK is due to background radiation [114]. He still is the proponent of the idea that the embryo is more vulnerable to the carcinogenic effects of radiation than the child.

(c) I am not one who is reluctant to make predictions. I agree with Martha Linet regarding the risks of embryonic ionizing radiation. However, I would predict that in the next 20 years we will learn that the risk of cancer from embryonic radiation will be further reduced from the findings of the Preston et al. 2008 study. At my present age I will not be alive to know the results. I believe that the omnipotential (stem) cells protective effect that was present in the embryo at the time of the radiation will continue to be manifested.

\subsection{Counseling an individual patient}

If a pregnant woman has had a diagnostic radiological procedure that exposed her embryo or who has been scheduled for an Xray that will expose her embryo and is concerned about the increased risk of cancer from the exposure, how should a counselor respond?

The majority of diagnostic radiological studies expose the embryo to $<0.10 \mathrm{~Gy}$ ( $<10 \mathrm{rad}$ ) which is a very low exposure. Based on all the studies we have available, the risk of cancer to the embryo is very low and possibly so low that we may never be able to measure the risk. Therefore, diagnostic radiological studies that are considered to be important for optimal patient care should be performed. It is important to be aware of the background risk of cancer for all individuals, which is $23 \%$ for potentially lethal cancers. Fortunately, each year the percentage of cancers that are cured is increasing. The background risk of cancer is hundreds or more times the theoretical risks of diagnostic radiological exposures to the embryo.

\section{Conflict of interest statement}

None declared.

\section{Funding sources}

None.

\section{References}

[1] Brent RL, Jordan HC. Possible late tumor development in rat embryos irradiated with $100 \mathrm{r}$ of $\mathrm{x}$-radiation on the 9th day of gestation. Anat Rec 1951:109:13 (abstract).

[2] Wilson JG, Brent RL, Jordan HC. Neoplasia induced in rat embryos by roentgen irradiation. Cancer Res 1952;12:222-8 (also appeared in USAECD UR-183, 1951).

[3] Russell LB. X-ray induced developmental abnormalities in the mouse and their use in analysis of embryological patterns. I. External and gross visceral changes. J Exp Zool 1950;114:345-602.

[4] Russell LB. X-ray-induced developmental abnormalities in the mouse and their use in analysis of embryological patterns. II. Abnormalities of the vertebral column and thorax. J Exp Zool 1956;131:329-95.

[5] Wilson JG, Brent RL, Jordan HC. Differentiation as a determinant of the reaction of rat embryos to x-irradiation. Proc Soc Exp Biol Med 1953;82:67-70 (also appeared in USAECD UR-243, 1953).

[6] Brent RL, Bolden BT. Indirect effect of X-irradiation on embryonic development. V. Utilization of high doses of maternal irradiation on the first day of gestation. Rad Res 1968;36:563-70.

[7] Stewart A, Kneale GW. Radiation dose effects in relation to obstetric X-rays and childhood cancers. Lancet 1970;1:1185-8.

[8] Stewart A, Webb D, Giles D. Malignant disease in childhood and diagnostic irradiation in utero. Lancet 1956;2:447.

[9] Giles D, Hewitt D, Stewart A, Webb J. Malignant disease in childhood and diagnostic irradiation in utero. Lancet 1956;271(6940):447.

[10] Stewart A, Webb D, Hewitt D. A survey of childhood malignancies. BM] 1958;1:1495-508.

[11] National Academy of Sciences/National Research Council. The effects of populations of exposure to low levels of ionizing radiation. Report of the Advisory Committee on the Biological Effects of Ionizing Radiations. Washington, DC: NAS/NRC; 1972.

[12] Lewis EB. Leukemia and ionizing radiation. Science 1957:125:865-972.

[13] Short \& others v. BNFL and others. Legal case, World Court decision, 1999.

[14] Kneale GW, Stewart AM. Age variation in the cancer risks from foetal irradiation. Br J Cancer 1977;36:501-10. 
[15] Klein M. Induction of lung adenomas following exposure of pregnant, newborn, and immature male mice to urethane. Cancer Res 1954;14:438-40.

[16] Vesselinovitch SD, Mihailovich N, Rao KVN, Itze L. Perinatal carcinogenesis by urethane. Cancer Res 1971;31:2143-7.

[17] Lilienfeld AM. Epidemiological studies of the leukemogenic effects of radiation. Yale J Biol Med 1966;39:143-64.

[18] Polhemus D, Koch R. Leukemia and medical irradiation. Pediatrics 1959;23: 453-61.

[19] Ford D, Patterson T. Fetal exposure to diagnostic x-rays and leukemia and other malignant diseases in childhood. J Natl Cancer Inst 1959;22:1093-104.

[20] Graham S, Levin MI, Lilienfeld AM. Preconception, intrauterine and postnatal irradiation as related to leukemia. J Natl Cancer Inst Monogr 1966;19:347-71.

[21] MacMahon B. Prenatal X-ray exposure and twins. N Engl J Med 1985;312: $576-7$.

[22] Diamond EL, Schmerler H, Lilienfeld AM. The relationship of intrauterine radiation to subsequent mortality and development of leukemia in children: a prospective study. Am J Epidemiol 1973;97:283-313.

[23] MacMahon B, Hutchinson GB. Prenatal X-ray and childhood: a review. Acta Union Int Contra Cancrum 1964;20:1172-4.

[24] Bithell JF, Stewart AM. Prenatal irradiation and childhood malignancy: a review of British data from the Oxford Survey. Br J Cancer 1975;31:271-87.

[25] Van Steensel-Moll HA, Valkenburg HA, Vandenbroucke JP, Van Zanen GE. Are maternal fertility problems related to childhood leukaemia? Int J Epidemiol 1985; $14: 555-9$.

[26] Shu XO, Gao YT, Brinton LA, Linet MS, Tu JT, Zheng W, et al. A populationbased case-control study of childhood leukemia in Shanghai. Cancer 1988;62:635-44.

[27] Magnani C, Pastore G, Luzzatto L, Terracini B. Parental occupation and other environmental factors in the etiology of leukemias and non-Hodgkin's lymphomas in childhood: a case-control study. Tumori 1990;76:413-9.

[28] Naumberg E, Bellocco R, Cnattingius S, Hall P, Boice Jr JD, Ekbom A. Intrauterine exposure to diagnostic x-rays and risk of childhood leukemia subtypes. Radiat Res 2001;156:718-23.

[29] Shu XO, Potter JD, Linet MS, Severson RK, Han D, Kersey JH, et al. Diagnostic $\mathrm{X}$-rays and ultrasound exposure and risk of childhood acute lymphoblastic leukemia by immunophenotype. Cancer Epidemiol Biomarkers Prev 2002;11:177-85.

[30] Van Duijn CM, Van Steensel-Moll HA, Coebergh JW, Van Zanen GE. Risk factors for childhood acute non-lymphocytic leukemia: an association with maternal alcohol consumption during pregnancy? Cancer Epidemiol Biomarkers Prev 1994;3:457-60.

[31] Kaplan HS. An evaluation of the somatic and genetic hazards of the medical uses of radiation. Am J Roentgenol Radium Ther Nuc Med 1958;80:696-706.

[32] Salonen T, Saxen L. Risk indicators in childhood malignancies. Int J Cancer $1975 ; 15: 941-6$.

[33] Hirayama T. Descriptive and analytical epidemiology of childhood malignancy in Japan. In: Kobayashi N, editor. Recent advances in management of children with cancer. Tokyo: Children's Cancer Association of Japan; 1979. pp. 27-43.

[34] Monson RR, MacMahon B. Prenatal x-ray exposure and cancer in children. In: Boice Jr JD, Fraumeni JF, editors. Radiation carcinogenesis: epidemiology and biological significance. New York: Raven Press; 1984. pp. 97-105.

[35] Shu X-O, Reaman GH, Lampkin B, Sather HN, Pendergrass TW, Robison LL. Association of paternal diagnostic X-ray exposure with risk of infant leukemia. Investigators of the Children's Cancer Group. Cancer Epidemiol Biomarkers Prev 1994;3:645-53.

[36] Infante-Rivard C, Mathonnet G, Sinnett D. Risk of childhood leukemia associated with diagnostic irradiation and polymorphisms in DNA repair genes. Environ Health Perspect 2000;108:495-8.

[37] Infante-Rivard C, Deadman JE. Maternal occupational exposure to extremely low frequency magnetic fields during pregnancy and childhood leukemia. Epidemiology 2003;14:437-41.

[38] Rajaraman P, Simpson J, Neta G, Berrington de Gonzalez A, Ansell P, Linet MS, et al. Early life exposure to diagnostic radiation and ultrasound scans and risk of childhood cancer: case-control study. Br Med J 2011;342:d472.

[39] Preston-Martin S, Yu MC, Benton B, Henderson BE. N-Nitroso compounds and childhood brain tumors: a case-control study. Cancer Res 1982;42: 5240-5.

[40] Bunin GR, Buckley JD, Boesel CP, Rorke LB, Meadows AT. Risk factors for astrocytic glioma and primitive neuroectoderman tumor of the brain in young children: a report from the Children's Cancer Group. Cancer Epidemiol Biomarkers Prev 1994;3:197-204.

[41] Schuz J, Kaletsch U, Kaatsch P, Meinert R, Michaelis J. Risk factors for pediatric tumors of the central nervous system: results from a German population-based case-control study. Med Pediatr Oncol 2001;36:27482.

[42] Stalberg K, Haglund B, Axelsson O, Cnattingius S, Pfeifer S, Kieler H. Prenatal $\mathrm{X}$-ray exposure and childhood bran tumours: a population-based case-control study on tumor subtypes. Br J Cancer 2007;97:1583-7.

[43] Winn DM, Li FP, Robison LL, Mulvihill JJ, Daigle AE, Fraumeni Jr JF. A casecontrol study of the etiology of Ewing's sarcoma. Cancer Epidemiol Biomarkers Prev 1992;1:525-32.

[44] Gufferman S, Ruymann F, Ognjanovic S, Erhardt EB, Maurer HM. Prenatal Xray exposure and rhabdomyosarcoma in children: a report from the Children's Oncology Group. Cancer Epidemiol Biomarkers Prev 2009;18:1271-6.
[45] MacMahon B. Prenatal X-ray exposure and childhood cancer. J Natl Cancer Inst 1962:28:1173-91.

[46] Little MP. A comparison of the risk of stillbirth associated with paternal preconception irradiation in the Sellafield workforce with that of stillbirth and untoward pregnancy outcome among Japanese atomic bomb survivors. J Radiol Prot 1999;14:361-73.

[47] Knox EG, Stewart AM, Kneale GW, Gilman EA. Prenatal irradiation and childhood cancer. J Soc Radiol Prot 1987;7:177-88.

[48] Ross MH, Bras G. Tumor incidence patterns and nutrition in the rat. J Nutr 1965;87:245-60.

[49] Shiono PH, Chung CS, Myrianthopoulos NC. Preconception radiation, intrauterine diagnostic radiation, and childhood neoplasia. J Natl Cancer Inst 1980;65:681-6.

[50] Court-Brown WM, Doll R, Hill RB. Incidence of leukemia after exposure to diagnostic radiation in utero. BMJ 1960;2:1539-45.

[51] Salonen T. Prenatal and perinatal factors in childhood cancer. Ann Clin Res $1976 ; 8: 27-42$.

[52] Murray R, Heckel P, Hempelmann LH. Leukemia in children exposed to ionizing radiation. N Engl J Med 1959;261:585-9.

[53] Lewis TLT. Leukaemia in childhood after antenatal exposure to X-rays. Br Med J 1960;2:1551.

[54] Griem ML, Meier P, Dobben G. Analysis of the morbidity and mortality of children irradiated in fetal life. Radiology 1967;88:347-9.

[55] Oppenheim BE, Griem ML, Meier P. Effects of low-dose prenatal irradiation in humans: analysis of Chicago lying-in data and comparisons with other studies. Radiat Res 1974;57:508-44.

[56] Oppenheim BE, Griem ML, Meier P. The effects of diagnostic X-ray exposure on the human fetus. An examination of the evidence. Radiology 1975;114: 529-34.

[57] Golding J, Paterson M, Kinlen LJ. Factors associated with childhood cancer in a national cohort study. Br J Cancer 1990;62:304-8.

[58] ICRP International Commission on Radiological Protection. Pregnancy and medical radiation, ICRP Publication 84, Ann ICRP, vol. 30(1). New York: Elsevier; 2003.

[59] Dempster WH. Radiation hazard in antenatal radiography. Lancet 1958;272: 159.

[60] Milis SD, Bruwer AJ, Banner EA, Davis GD, Gage RP. Effects of irradiation of the fetus: ten-year follow-up of pelvimetry during pregnancy. Minn Med 1958;41:339-41.

[61] Lejeune J, Turpin R, Rethore MO, Mayer M. Results of a first investigation of the somatic effects of fetoembryonal irradiation in utero (special case of heterochromia iridis). Rev Fr Etudes Clin Biol 1960;5:982-9 (in French).

[62] Magnin P. The fate of infants irradiated in utero. Analysis of a survey involving 5,353 cases. Presse Med 1962;70:1199-202 (in French).

[63] Nokkentved K. Effects of radiation upon the human fetus. Follow-up study of 152 children exposed to irradiation during the first 4 months of foetal life due to X-ray examination of the maternal abdomen. Copenhagen: Ejnar Munksgaards Forlag; 1968.

[64] Hagstrom RM, Glasser SR, Brill AB, Heyssel RM. Long term effects of radioactive iron administered during human pregnancy. Am J Epidemiol 1969;90: $1-10$.

[65] Ray JG, Schull MJ, Urquia ML, You JJ, Guttmann A, Vermeulen MJ. Major radiodiagnostic imaging in pregnancy and the risk of childhood malignancy: a population-based cohort study in Ontario. PloS Med 2010;7:1-8.

[66] Doll R, Wakeford R. Risk of childhood cancer from fetal irradiation. Br J Radiol 1997;70:130-9.

[67] Preston DL, Cullings H, Suyama A, Funamoto S, Nishi N, Soda M, et al. Solid cancer incidence in atomic bomb survivors exposed in utero or as young children. J Natl Cancer Inst 2008;100:428-36.

[68] Hoshino T, Itoga T, Kato H. Leukemia in the offspring of parents exposed to the atomic bomb at Hiroshima and Nagasaki. Presented at the Japanese Association of Hematology, Japan, 25-30 March 1965.

[69] Miller RW. Epidemiological conclusions from radiation toxicity studies. In: Fry RJM, Grahn D, Greim ML, editors. Late effects of radiation. London: Taylor \& Francis; 1970. pp. 245-56.

[70] Brent RL, Gorson RO. Radiation exposure in pregnancy. In: Moseley RD Baker DH, Gorson RO, editors. Current problems in radiology. Chicago: Year Book Medical Publishers; 1972. pp. 1-48.

[71] Jablon S. Comments. Health Phys 1973;24:257-8.

[72] Miller RW. Discussion. Severe mental retardation and cancer among atomic bomb survivors exposed in utero. Teratology 1999;59:234-5.

[73] Brent RL. Utilization of developmental basic science principles in the evaluation of reproductive risks from pre- and postconception environmental radiation exposures. Teratology 1999;59:182-204.

[74] Brent RL. Radiation teratogenesis. Teratology 1980;21:218-98.

[75] Wood J, Johnson KG, Omori Y. Mental retardation in children exposed in utero to the atomic bombs in Hiroshima and Nagasaki. Am J Public Health 1967; 57:1381-90.

[76] Wood J, Keehn R, Kawamoto S. The growth and development of children exposed in utero to the atomic bombs in Hiroshima and Nagasaki. Am J Public Health 1967;57:1374-80.

[77] Maroteaux P, Spranger J, Opitz JM. Le syndrome campomelique. Presse Med 1971;22:1157-62.

[78] Boice Jr JD, Miller RW. Childhood and adult cancer following intrauterine exposure to ionizing radiation. Teratology 1999;59:227-33. 
[79] Boice Jr JD, Inskip PD. Radiation-induced leukemia. In: Henderson ES, Lister TA, Greaves MF, editors. Leukemia. 6th ed. Philadelphia: Saunders; 1996. pp. 195-209.

[80] Delongchamp RR, Mabuchi K, Yoshimoto Y, Preston DL. Cancer mortality among atomic bomb survivors exposed in utero or as young children, October 1950-May 1992. J Radiat Res (Tokyo) 1997;147:385-95.

[81] Miller RW, Boice Jr JD. Cancer after intrauterine exposure to the atomic bomb. J Radiat Res (Tokyo) 1997;147:396-7.

[82] Muirhead CR, Kneale GW. Prenatal irradiation and childhood cancer. J Radiol Prot 1989;9:209-12.

[83] National Radiological Protection Board. Diagnostic medical exposures: advice on exposure to ionizing radiation during pregnancy. Joint Guidance from NRPB/CoR/RCR. Chilton, UK: NRPB; 1998.

[84] Pierce DA, Shimizu Y, Preston DL, Vaeth M, Mabuchi K. Studies of the mortality of atomic bomb survivors. Report 12, Part I. Cancer: 1950-1990. J Radiat Res (Tokyo) 1996;146:1-27.

[85] Thompson DE, Mabuchi K, Ron E, Soda M, Tokunaga M, Ochikubo S, et al Cancer incidence in atomic bomb survivors. Part II. Solid tumors 1958-1987. J Radiat Res (Tokyo) 1994;137:S17-67.

[86] Yoshimoto Y, Delongchamp R, Mabuchi K. In utero exposed atomic bomb survivors: cancer risk update. Lancet 1994;344:345-6.

[87] Harvey EB, Boice Jr JD, Honeyman M, Flannery JT. Prenatal x-ray exposure and childhood cancer in twins. N Engl J Med 1985;312:541-5.

[88] Rodvall Y, Pershagen G, Hrubec Z, Ahlbom A, Pedersen NL, Boice Jr JD. Prenatal X-ray exposure and childhood cancer in Swedish twins. Int J Cancer 1990;46:362-5.

[89] Mole RH. Antenatal irradiation and childhood cancer: causation or coincidence? Br J Cancer 1974;30:199-208.

[90] Doll R, Wakeford R. Carcinogenesis after exposure to ionizing radiation. Invest Rad 2000:35:527-33.

[91] UNSCEAR United Nations Scientific Committee on the Effects of Atomic Radiation. Sources and effects of ionizing radiation, UNSCEAR 1994. Report to the General Assembly with Scientific Annexes, No. E.94IX.11. New York: United Nations Publications; 1994.

[92] Bithell JF, Stiller CA. A new calculation of the carcinogenic risk of obstetric xraying. Stat Med 1988;7:857-64.

[93] Jablon S, Kato H. Mortality among a-bomb survivors, 1950-1970. Technical report 10-71. Hiroshima: Radiation Effects Research Foundation; 1970.

[94] Miller RW. Delayed radiation effects in atomic-bomb survivors. major observations by the Atomic Bomb Casualty Commission are evaluated. Science 1969;166:569-74.

[95] NAS/NRC (National Academy of Sciences/National Research Council). Health effects of exposure to low levels of ionizing radiation. Committee on the Biological Effects of Ionizing Radiations. BEIR V. Washington, DC: National Academy Press; 1990.

[96] Inskip PD, Harvey EB, Boice Jr JD, Stone BJ, Matanoski G, Flannery JT, et al. Incidence of childhood cancer in twins. Cancer Causes Control 1991;2: 315-24.

[97] Rodvall Y, Pershagen G, Hrubec Z, Alhbom A, Pedersen NL, Boice Jr JD. Childhood cancer among Swedish twins. Cancer Causes Control 1992;3: $527-32$.

[98] UNSCEAR (United Nations Scientific Committee on the Effects of Atomic Radiation). Ionizing radiation: levels and effects. A Report of the United
Nations Scientific Committee on the Effects of Atomic Radiation to the General Assembly, with Annexes. No. E.72.IZ.17. New York: United Nations Publications; 1986.

[99] Upton AC, Odell Jr TT, Sniffen EP. Influences of age at time of irradiation on induction of leukemia and ovarian tumors in RF mice. Proc Soc Exp Biol Med 1960;104:769-72.

[100] Doll R, Wakeford R. Survivors exposed in utero or as young children. J Natl Cancer Inst 2008;100:1482-3.

[101] Wakeford R, Little MP. Risk coefficients for childhood cancer after intrauterine irradiation: a review. Int J Radiat Biol 2003;79:293-309.

[102] Brent RL, Bushberg JT, Linet M, et al., editors. NCRP Report No. 174. Preconception and prenatal radiation exposure: health effects and protective guidance 24 May 2013. p. 351. Recommendations of the National Council on Radiation Protection and Measurements, Bethesda, MD, USA.

[103] Preston DL, Kusumi S, Tomonaga M, Izami S, Ron E, Kuramoto A, et al. Cancer incidence in atomic bomb survivors. Part III. Leukemia, lymphoma and multiple myeloma, 1950-1987. Radiat Res 1994;137(2 Suppl.):S68-97.

[104] DiMajo V, Coppola M, Rebessi S, Covelli V. Age-related susceptibility of mouse liver to induction of tumors by neutrons. Radiat Res 1990;124: 227-34.

[105] Sasaki S. Influence of the age of mice at exposure to radiation on lifeshortening and carcinogenesis. J Radiat Res (Tokyo) 1991;32(Suppl.): $73-85$.

[106] Nomura T, Nakajima H, Hatanaka T, Kinuta M, Hongyo T. Embryonic mutation as a possible cause of in utero carcinogenesis in mice revealed by postnatal treatment with 12-0-tetradecanoylphorbol-13-acetate. Cancer Res 1990;50:2135-8.

[107] Schmahl W, Kriegel H, Senft E. Can prenatal X-irradiation in mice act as an initiator stimulus in a modified 2-stage Berenblum/Mottram experiment with postnatal promotion with phorbol ester TPA? J Cancer Res Clin Oncol 1980;97:109-17.

[108] Uma-Devi P, Hossain M. Induction of solid tumours in the Swiss albino mouse by low-dose foetal irradiation. Int J Radiat Biol 2000;76:366-72.

[109] Ellender M, Harrison JD, Kozlowski R, Suzluinska M, Bouffler SD, Cox R. In utero and neonatal sensitivity of ApeMin/+ mice to radiation-induced intestinal neoplasia. Int J Radiat Biol 2006;82:141-51.

[110] Rugh R, Duhamel L, Skaredoff L. Relation of embryonic and fetal x-irradiation to life time average weights and tumor incidence in mice. Proc Soc Exp Biol Med 1966;121:714-8.

[111] Benjamin SA, Lee AC, Angleton GM, Saunders WJ, Keefe TJ, Mallinckrodt $\mathrm{CH}$. Mortality in beagles irradiated during prenatal and postnatal development. I. Contribution of non-neoplasia diseases. Radiat Res 1998;150:330-48.

[112] Warkany J, Mandybur TI, Kalter H. Oncogenic response of rats with X-rayinduced microcephaly to transplacental ethylnitrosourea. J Natl Cancer Inst 1976;56:59-64.

[113] Nakano M, Kodama Y, Ohtaki K, Nakashima E, Niwa O, Toyoshima M, et al. Chromosome aberrations do not persist in the lymphocytes or bone marrow cells of mice irradiated in utero or soon after birth. Radiat Res 2007;167: 693-702.

[114] Wakeford R, Kendall GM, Little MP. The proportion of childhood leukaemia incidence in Great Britain that may be caused by natural background ionizing radiation. Leukemia 2009;24:770-6. 